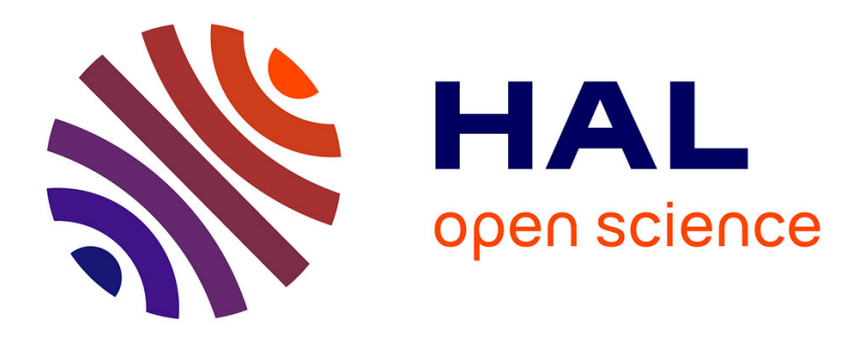

\title{
Enzyme collagen membrane for electrochemical determination of glucose
}

Daniel R. Thevenot, Robert Sternberg, Pierre R. Coulet, Jean Laurent, Danièle C. Gautheron

\section{- To cite this version:}

Daniel R. Thevenot, Robert Sternberg, Pierre R. Coulet, Jean Laurent, Danièle C. Gautheron. Enzyme collagen membrane for electrochemical determination of glucose. Analytical Chemistry, 1979, 51, pp.96 - 100. 10.1021/ac50037a031 . hal-01179308

\section{HAL Id: hal-01179308 \\ https://hal.science/hal-01179308}

Submitted on 23 Jul 2015

HAL is a multi-disciplinary open access archive for the deposit and dissemination of scientific research documents, whether they are published or not. The documents may come from teaching and research institutions in France or abroad, or from public or private research centers.
L'archive ouverte pluridisciplinaire HAL, est destinée au dépôt et à la diffusion de documents scientifiques de niveau recherche, publiés ou non, émanant des établissements d'enseignement et de recherche français ou étrangers, des laboratoires publics ou privés. 


\title{
Enzyme Collagen Membrane for Electrochemical Determination of Glucose
}

\author{
Daniel R. Thévenot* and Robert Stemberg \\ Equipe de Bioélectrochimie et d'Analyse du Milieu, Laboratoire d'Energetique Biochimique, Universitê Paris Val de Marne, Avenue du \\ Genéral de Gaulle, F94010, Créteil Cédex, France
}

Pierre R. Coulet, Jean Laurent, and Danièle C. Gautheron

Laboratoire de Biologie et Technologie des Membranes du CNRS, Universite Claude Bernard, Lyon 1, 43, boulevard du 11 novembre 1918, F69621, Villeurbanne, France

\begin{abstract}
A new trace glucose analyzer has been designed using electrochemical sensors. The differential device includes (a) a glucose sensor consisting of a modified gas electrode in which the $\mathrm{pH}$ detector was replaced by a platinum disk and the porous film by a collagen membrane on which $\beta$-D-glucose oxidase has been covalently bound after an acyl-azide activation process; (b) a compensating electrode mounted with a nonenzymatic collagen membrane. After injection of a glucose containing sample into the reaction vesse!, where the probes are immersed, an anodic current is detected at the enzyme working electrode. Current outputs of both electrodes are subtracted and twice differentiated; a steady state is reached and the stationary and dynamic responses are recorded. Both responses are proportional to glucose concentration in the $0.1 \mu \mathrm{M}-2 \mathrm{mM}$ range, and the reproductibility was found to be better than $2 \%$ using these conditions. The extreme sensitivily exhibited by our system, i.e., $10 \mathrm{nM}$, is better than previously reported data by 3 orders of magnitude, and is very favorable for trace glucose assays in food and biological samples.
\end{abstract}

The association of electrochemical sensors with enzymatic films, leading to the so-called enzyme electrodes, is a rapidly expanding analytical method $(1,2)$. In the presence of glucose oxidase (GOD), glucose is oxidized according to the reaction:

$$
\beta \text {-D-glucose }+\mathrm{O}_{2} \stackrel{\text { GOD }}{\rightarrow} \text { gluconic acid }+\mathrm{H}_{2} \mathrm{O}_{2}
$$

$\mathrm{H}_{2} \mathrm{O}_{2}$ formation is usually followed by reaction with a chromogenic precursor in the presence of peroxidase, including a necessary incubation time before measurement. An alternative method is the anodic oxidation of $\mathrm{H}_{2} \mathrm{O}_{2}$ :

$$
\mathrm{H}_{2} \mathrm{O}_{2} \rightarrow \mathrm{O}_{2}+2 e^{-}+2 \mathrm{H}^{+}
$$

leading to the design of glucose sensors $(3,4)$. Furthermore, entrapment of GOD in an immobilized form avoids the drawbacks encountered when using an enzyme solution (1, 4).

In the present work, reconstituted collagen membranes having undergone an acyl-azide activation process and bearing covalently bound GOD were associated to the amperometric detection of $\mathrm{H}_{2} \mathrm{O}_{2}$ for the determination of traces of glucose $(5,6)$.

\section{EXPERIMENTAL}

Instrumentation. The glucose sensor consisted of two electrodes; both electrodes contained a platinum disk and a collagen membrane maintained in close contact by a screwed cap (Figure 1). Common auxiliary electrodes (A) were platinum wires and references $(R)$ were $\mathrm{Ag} / \mathrm{AgCl}$. Electrodes $\mathrm{E}_{1}$ and $\mathrm{E}_{2}$ were filled with $0.2 \mathrm{M}$ acetate buffer, $0.1 \mathrm{M} \mathrm{KCl}, \mathrm{pH} 5.6$, and mounted with both a $\beta$-D-glucose oxidase (GOD, EC 1.1.3.4) collagen membrane and a nonenzymatic one, respectively. The electrodes were either dipped into the buffer solution or mounted with flow-through caps as shown on Figure 1. In the latter case, the flow rate was constant and equal to $0.7 \mathrm{~mL} / \mathrm{min}$. A potential difference of $650 \mathrm{mV}$ was maintained between the platinum working electrodes $W_{1}$ and $W_{2}$ and a reference $R$, by a potentiostat. Current outputs of $W_{1}$ and $\mathrm{W}_{2}$ were first subtracted, and then twice differentiated with a time base of $1 \mathrm{~s}$ (Figure 2). Thus, 4 different current vs. time curves were available and usually recorded after a glucose pulse.

Electronics were supplied by Solea Tacussel (Villeurbanne, France) and consisted of a Deltapol differential current amplifier, PRG5 potentiostat, a Minisis millivoltmeter, and a Derivol derivating amplifier. Recorders were Solea Tacussel EPL 2, with a TV 11 GD plug-in unit and three-traces Linear 395.

Unless otherwise mentioned, the temperature of all solutions was carefully thermostated at $30.0 \pm 0.1^{\circ} \mathrm{C}$ (Colora cryothermostat WK 5 DS).

Solutions and Reagents. Insoluble films of highly polymerized reconstituted collagen $(20 \mathrm{~cm}$ wide) were a gift of the Centre Technique du Cuir (Lyon, France). Their thickness is about 0.1 $\mathrm{mm}$ in dry state and from 0.3 to $0.5 \mathrm{~mm}$ when swollen. They do not need to be tanned and can be used several years without damage $(7,8)$

Lyophilized $\beta$-D-glucose oxidase (GOD, EC 1.1.3.4) grade I, peroxidase (POD, EC 1.11.1.7), beef liver catalase (EC 1.11.1.6), and 2,2'-azinodi(3-ethylbenzthiazoline sulfonate) (6) (ABTS) were supplied by Boehringer, France.

Unless otherwise mentioned, all chemicals used were reagent grade. The stock solution of $0.1 \mathrm{M}$ glucose was allowed to mutarotate at room temperature at least $3 \mathrm{~h}$ before use, and was stored at $4^{\circ} \mathrm{C}$. Both electrodes were filled and dipped in $0.2 \mathrm{M}$ acetate buffer- $-0.1 \mathrm{M} \mathrm{KCl}$ solutions ( $\mathrm{pH}$ 5.6). The stock solution of $0.1 \mathrm{M} \mathrm{H}_{2} \mathrm{O}_{2}$ was frequently assayed by titration with $0.1 \mathrm{~N}$ $\mathrm{Ce}\left(\mathrm{SO}_{4}\right)_{2}$ using ferrous 0 -phenanthroline as indicator.

Enzyme Assay for Free and Bound GOD. Two different methods were used to measure GOD activity in $0.1 \mathrm{M}$ glucose solution, following gluconic acid or $\mathrm{H}_{2} \mathrm{O}_{2}$ formation.

(a) Gluconic acid was titrated by use of a pH-stat in an unbuffered medium containing $0.9 \mathrm{~mL}$ of $0.5 \mathrm{M}$ glucose, $0.1 \mathrm{~mL}$ of $1 \mathrm{mg} / \mathrm{mL}$ beef liver catalase, and $3.5 \mathrm{~mL}$ distilled water (regulated to $\mathrm{pH} 6$ by addition of $10 \mathrm{mM} \mathrm{KOH}$ ); the equipment consisted of a commercially available $\mathrm{pH}$-stat device coupled to a microburet and a recorder: either Urectron 4, Electroburex buret and EPL2 recorder from Solea-Tacussel were used, or Metrohm E 300B and 473, Solea-Tacussel Electroburap buret and Sefram graphispot recorder. In routine experiments, $1 \mathrm{~cm}$ on the recording chart corresponded to $16 \mu \mathrm{L}$ delivered by the microburet.

(b) Hydrogen peroxide formation was followed using the POD-ABTS reagent: after addition of $0.2-\mathrm{mL}$ samples into 0.8 $\mathrm{mL}$ of reagent $(0.02 \mathrm{mg} / \mathrm{mL}$ POD and $1.0 \mathrm{mg} / \mathrm{mL}$ ABTS $)$ the blue coloration was followed at $420 \mathrm{~nm}$.

Procedure. Both electrodes $\mathrm{E}_{1}$ and $\mathrm{E}_{2}$ were allowed to equilibrate in the buffer solution during 15 to $30 \mathrm{~min}$ after stepping the potential of the working electrodes to $+650 \mathrm{mV}$ vs. $\mathrm{Ag} / \mathrm{AgCl}$ 


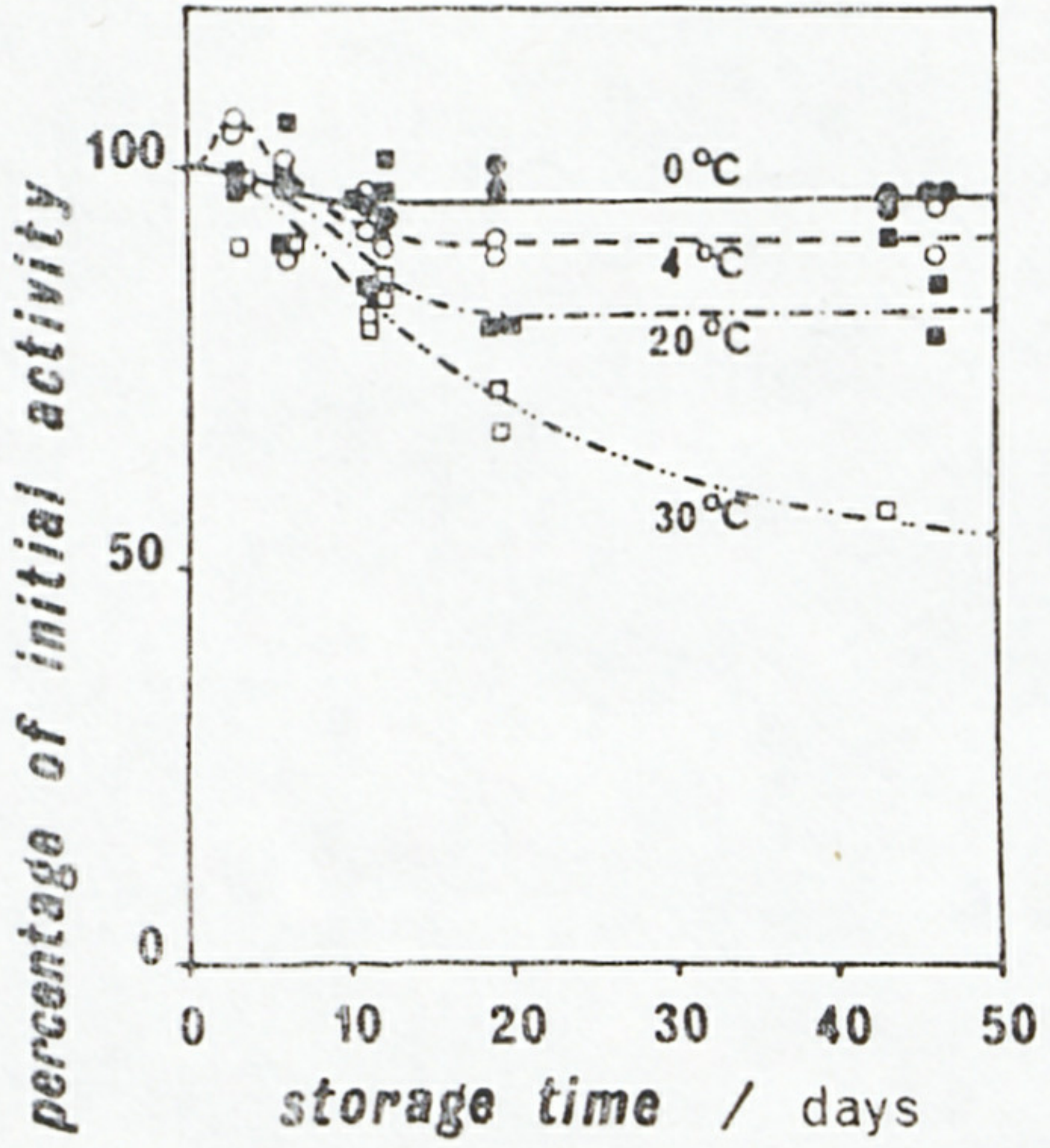

Figure 5. Influence of the temperature of storage on the maintenance of collagen bound GOD activity. Acetate buffer $0.1 \mathrm{M}(\mathrm{pH} 4.5)$ at (0) 0, (O) 4 , (a) 20 , and (ㅁ) $30^{\circ} \mathrm{C}$

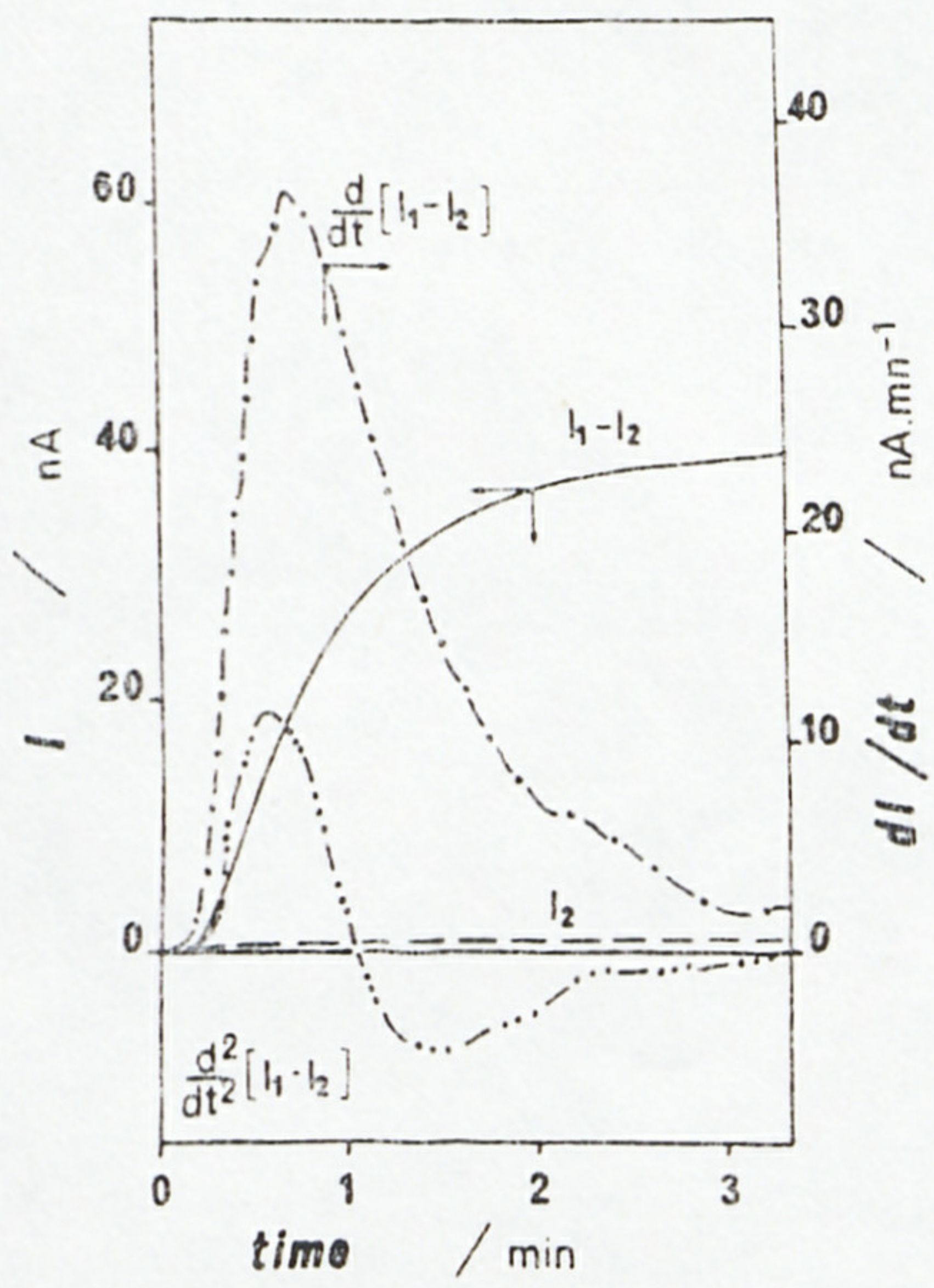

Figure 6. Response curves for a $10 \mu \mathrm{M}$ glucose pulse with the stationary electrodes. (-) $I_{1}-I_{2}$ vs. time: steady-state response. $(---) I_{2}$ vs. time: non-enzymatic response. (-..--) $\mathrm{d}\left(I_{1}-I_{2}\right) / \mathrm{d} t$ vs. time: dynamic response. $(\ldots \cdots \cdots) d^{2}\left(I_{1}-I_{2}\right) / d t^{2}$ vs. time: signal used in automated devices

that the use of such GOD membranes, in solutions thermostated at $30^{\circ} \mathrm{C}$ for several weeks, is possible.

\section{A SENSOR FOR THE DETERMINATION OF TRACES OF GLUCOSE}

The union of a GOD collagen membrane and an amperometric detector of $\mathrm{H}_{2} \mathrm{O}_{2}$, as described in Figure 1, yields a glucose sensor giving a response within $1 \mathrm{~min}$ and possessing a very high sensitivity (ca $10 \mathrm{nM}$ ).

When glucose is added to the buffer solution into which both electrodes $E_{1}$ and $E_{2}$ are dipped, or when the glucose concentration increases in a flow-through solution, 4 different current vs. time curves may be recorded (Figure 6).

$\mathrm{I}_{2}$ remains very small showing the absence of any GOD activity of activated collagen on $\mathrm{E}_{2}$.

$\left(I_{1}-I_{2}\right)$ reaches a steady-state value after 2 to $3 \mathrm{~min}$ : this is the steady-state response of the sensor.

$\mathrm{d}\left(I_{1}-I_{2}\right) / \mathrm{d} t$ is maximum after 30 to $50 \mathrm{~s}$ : the height of this peak is the dynamic response of the sensor.

$\mathrm{d}^{2}\left(I_{1}-I_{2}\right) / \mathrm{d} t^{2}$ may control a switch when reaching a null point, and be used for printing the dynamic response; this
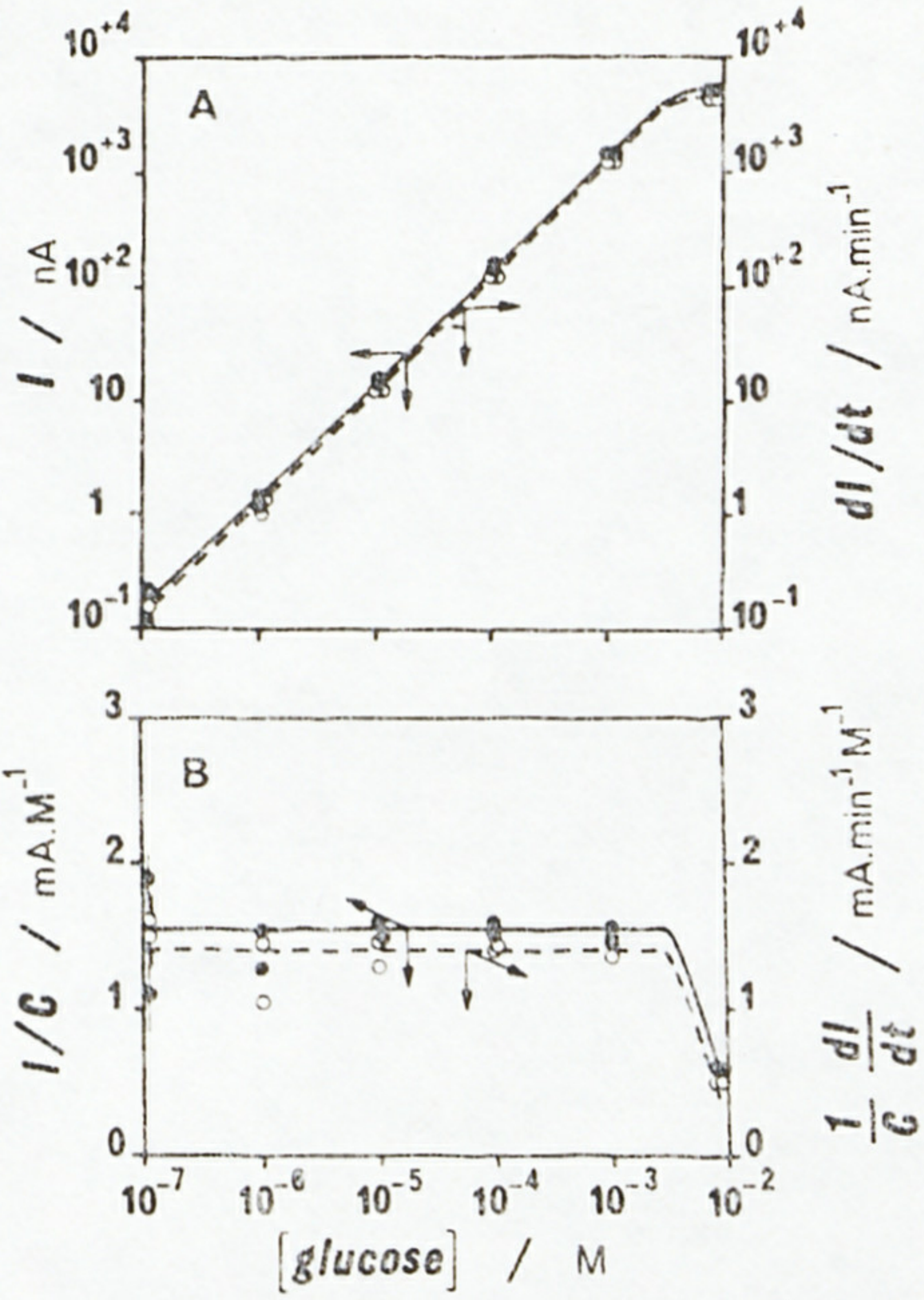

Figure 7. Calibration curves with stationary electrodes. $(-0-)$ steady-state and (- $\left.\mathrm{O}_{-}\right)$dynamic responses to glucose pulses. (A) $\log$ (responses) vs. log (glucose). (E) Relative responses vs. log (glucose)

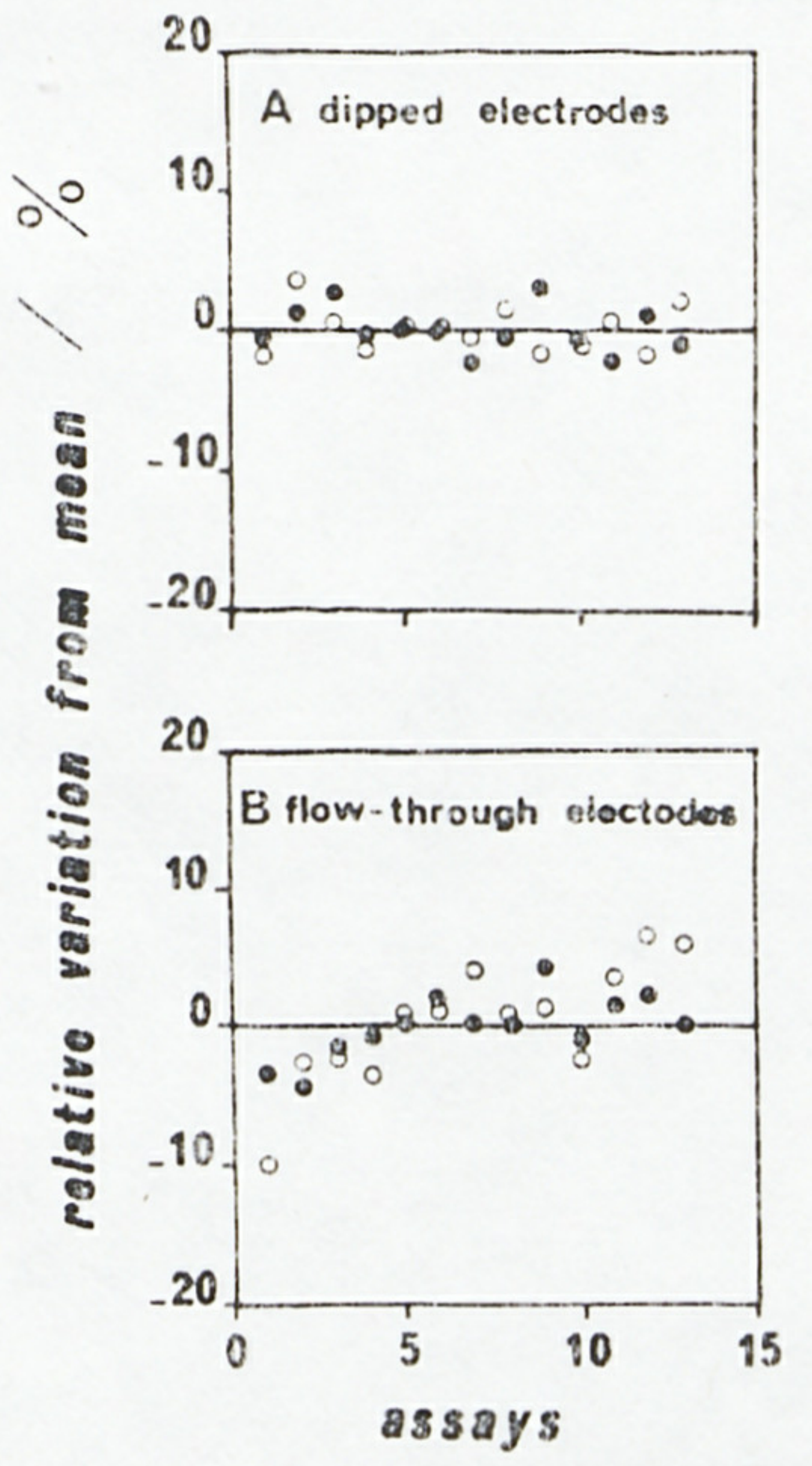

Figure 8. Determination of the precision of the glucose sensor by 13 successive assays. (O) steady-state and (O) dynamic responses for successive (A) $20 \mu \mathrm{M}$ and (B) $50 \mu \mathrm{M}$ glucose determinations

device was actually built and gave excellent results, although, because of electronic time-lag, the zero value of the second derivative is obtained ca. $15 \mathrm{~s}$ after the maximum of the first derivative.

Since both responses are proportional to glucose concentration over a very large range (Figures 7 and 8), successive glucose determinations are possible every 2 to $3 \mathrm{~min}$ without washing the electrodes. If, however, a washing is necessary, only about $3 \mathrm{~min}$ are required for the currents to return to their background values. The lowest glucose concentration which can be detected by the sensor is less than $10 \mathrm{nM}$ with the dipped electrodes and $100 \mathrm{nM}$ with the flow-through ones: for these extremely dilute solutions, the precision of glucose determination ranges between 50 and $100 \%$. The limit of detection depends on the noise level, which is somewhat less 
for steady-state than for dynamic responses, and for "dipped-in" than for flow-through electrodes. In the latter case, the noise level was mainly related to the irregularity of nlow-rates obtained with our peristaltic pump.

The sensor responses become independent of glucose concentration at concentrations higher than $10 \mathrm{mM}$ (Figure $7 \mathrm{~A})$; the concentrations which can be determined range from $10 \mathrm{nM}$ to $10 \mathrm{mM}$ (i.e., over 6 orders of magnitude). Linearity of the calibration curves, as tested by the concentration independence of the relative responses $I / C$ and $d I / C \cdot d t$ (Figure $7 \mathrm{~B})$, is observed over 4 to 5 concentration decades from ca 0.1 $\mu \mathrm{M}$ to $2-5 \mathrm{mM}$

\section{BASIC PROPERTIES OF THE GLUCOSE SENSOR}

Reproducibility. For definite values of the geometrical parameters of the system (electrodes-collagen membranes), the removal and remounting of the membranes on the platinum anode may shift the steady-state and dynamic glucose responses by 4 and $8 \%$, respectively.

Precision. The precision of glucose determinations has been tested during a set of experiments by successive additions of glucose concentrations into the same medium. The electrodes were either dipped into the solution (Figure 8A) or the solution was allowed to flow through them, in sequence with a pure buffer solution (Figure $8 B$ ). Both the steady-state and dynamic responses seem independent of the number of assays run within ca. $1 \mathrm{~h}$, and also independent of the number of $\mathrm{H}_{2} \mathrm{O}_{2}$ determinations. For 13 successive assays of a 20 and a $50 \mu \mathrm{M}$ glucose, the standard deviation from mean is usually lower than $2 \%$ and $4 \%$ using the stationary (dipped) and flow-through electrodes, respectively.

Selectivity. The selectivity depends on both the enzyme and the electrochemical detection method. GOD, itself, is very specific for $\beta$-D-glucose; so electrode $E_{1}$ (Figure 2) presents a high selectivity for glucose compared to usual sugars: the selectivity coefficient is smaller than $5.10^{-4}$ for glucose over fructose, lactose, and sucrose. A $1 \mathrm{mM}$ addition of these three sugars, either separately or mixed, gives a steady-state response lower than $1 \mathrm{nA}$, whereas a further addition of $1 \mathrm{mM}$ glucose gave a $3.5-\mu \mathrm{A}$ steady-state response. Since species other than enzymatically generated $\mathrm{H}_{2} \mathrm{O}_{2}$ may diffuse through the collagen membranes and be oxidized on platinum at +0.65 $\mathrm{V}$ vs. $\mathrm{Ag} / \mathrm{AgCl}$ (i.e., $0.94 \mathrm{~V} / \mathrm{NHE}$ ), the use of a compensating nonenzymatic electrode $\left(\mathrm{E}_{2}\right)$ eliminates the possible interferences of species such as $\mathrm{H}_{2} \mathrm{O}_{2}$, ascorbate, urate, and tyrosine. For example, an addition of $3.9 \mu \mathrm{M} \mathrm{H} \mathrm{H}_{2} \mathrm{O}_{2}$ will give a steady-state response at each electrode of about $35 \mathrm{nA}$ whereas the differential response $\left(I_{1}-I_{2}\right)$ is, after $2 \mathrm{~min}$, lower than $0.05 \mathrm{nA}$. Compared to the usual values of glucose steady-state responses $\left(1\right.$ to $\left.3 \mathrm{~mA} \cdot \mathrm{M}^{-1}\right)$, the selectivity coefficient for glucose over nonenzymatically generated $\mathrm{H}_{2} \mathrm{O}_{2}$ ranges between $4 \times$. $10^{-3}$ and $1.25 \times 10^{-2}$, depending upon experimental parameters (balance of the compensating electrode and GOD activity of the film).

Influence of GOD Activity. To study the relationship between the glucose responses of the sensor and the GOD membrane activity, membranes were prepared with various concentrations of GOD coupling solutions, leading to surface activities ranging from 4 to $80 \mathrm{nmol} \cdot \mathrm{min}^{-1} \cdot \mathrm{cm}^{-2}$. All these membranes were mounted on the same electrode $\left(E_{1}\right)$, and the calibration curves were determined in each case. When plotting the slopes of these calibration curves $(I / C)$ vs. the exhibited GOD activity, as shown on Figure 9, a linear relationship appears. This demonstrates that the rate limiting factor of the sensor is the GOD surface activity of the collagen membrane and that the best sensitivity is obtained with the most active enzyme membrane.

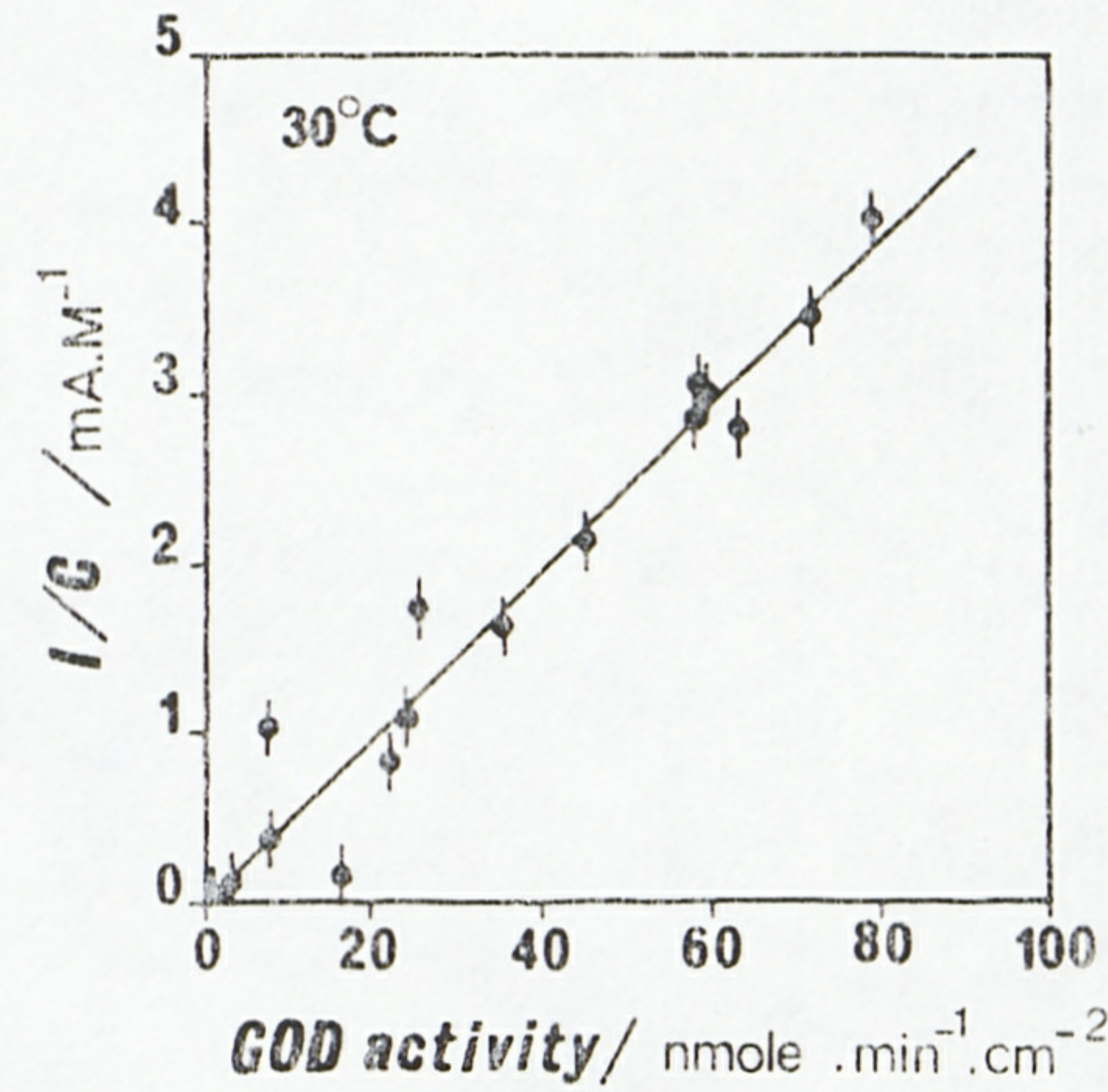

Figure 9. Influence of GOD activity of the collagen films on the slope of the calibration curve of the glucose sensor. Steady-state responses, $30^{\circ} \mathrm{C}$

Influence of Temperature. The sensor responses to glucose are as dependent on temperature as on the GOD activity of the collagen films. Because this dependence reaches $4-5 \% /{ }^{\circ} \mathrm{C}$ at $30{ }^{\circ} \mathrm{C}$ and $7-8 \% /{ }^{\circ} \mathrm{C}$ at $20^{\circ} \mathrm{C}$, it is necessary to carefully thermostat the solutions in contact with both electrodes. Nevertheless, the sensor may be used over a large temperature range: 15 to $40^{\circ} \mathrm{C}$

Storage. Besides the above mentioned high resistance of the GOD collagen films to bacterial degradation and GOD denaturation, we have observed excellent storage patterns for the glucose sensor, itself. For example, a given glucose electrode mounted with the same GOD membrane exhibited a decrease of less than $6 \%$ of the slopes of the calibration curves of the steady-state responses $(I / C)$, when stored at room temperature for more than 8 weeks, and checked at 30 ${ }^{\circ} \mathrm{C}$ for more than $60 \mathrm{~h}$ (cumulative time), totaling 310 glucose assays either in stock solutions or in output flow of bioreactors containing starch derivatives.

\section{CONCLUSION}

In a previous work, a generally useful mild coupling method for enzyme on collagen membranes using acyl-azide activation has been reported $(7,8)$. The excellent performances of such covalent binding allowed us to use these membranes in solid phase enzymology $(10,11)$, in bioreactors $(12,13)$, and as an active part of glucose sensors $(5,6)$. The proteinaceous environment provided by the collagen, itself, ensures a noticeable stability of the bound enzyme, either stored at $4^{\circ} \mathrm{C}$ for years, or mounted on an electrode at room temperature for months. No microbial attack was detected in our conditions of storage and utilization. Even with a low amount of bound enzyme $(50-100 \mathrm{mU} /$ membrane of $1-\mathrm{cm}$ diameter $)$, the device was found able to detect $10 \mathrm{nM}$ glucose solutions, the linearity of calibration curves obtained being from $100 \mathrm{nM}$ to $2 \mathrm{mM}$. The differential device, either with immersed or flow-through electrodes, can be used for the determination of traces of glucose in whole blood or plasma (6). The monitoring of glucose production in the output flow of bioreactors using starch derivatives as substrate and specific immobilized hydrolases is under investigation.

The potential of the described device, using either different oxidases or co-immobilized enzymes yielding $\mathrm{H}_{2} \mathrm{O}_{2}$, is very promising. In the latter case, glucose must be the product of the first enzymatic steps and GOD the final enzyme, ensuring the enzymatic oxidation of glucose and the production of $\mathrm{H}_{2} \mathrm{O}_{2}$. In all cases, the use of enzymes in an immobilized form, together with amperometric detection, avoids single-use expensive reagents, and leads to a low cost analytical device. 


\section{LITERATURE CITED}

(1) G. G. Guilbault, in "Immobilized Enzymes, Antigens, Antibodies and Peptides": H. H. Weetall, Ed., M. Dekker, New York, 1975, p 293.

(2) K. Camman, in "Das Arbeiten mit Ionenselectiven Electroden", Springer Verlag, New York, 1977, and Fresenius Z. Anal. Chem., 287, 1 (1977).

(3) L. C. Clark and C. Lyons, Ann. N.Y Acad. Sci., 102, 29 (1962)

(4) G. G. Guilbault and G. J. Lubrano, Anal. Chim. Acta, 64, 439 (1973).

(5) D. R. Thévenot, P. R. Coulet, R. Sternberg, and D. C. Gauotineron, in "Enzyme Engineering" Vol. 4, Plenum, New York, 1978, p 219.

(6) D. R. Thêvenot, P. R. Coulet, R. Sternberg, and D. C. Gautheron, Bioelectrochem. Bioenerg., 5, 541 (1978).

(7) P. R. Coulet, J. H. Julliard, and D. C. Gautheron, French patent (ANVAR) 73-23-283, publ number 2.235, 133 (1973).

(8) P. F. Coulet, J. H. Julliard, and D. C. Gautheron, Biotechnol. Bioeng.. 16, 1055 (1974)

(9) T. E. Barman, in "Enzyme Handbook", Vol. 1, Springer-Verlag, New York, 1969, p 112
(10) P. R. Coulet, C. Godinot, and D. C. Gautheron, Biochim. Biophys. Acta, 39 i, 272 (1975).

(11) J. M. Engasser, P. R. Coulet, and D. C. Gautheron, J. Biol. Chem., 252. 7919 (1977).

(12) J. M. Brillouet, P. R. Coulet, and D. C. Gautheron, Biotechnol. Bioeng., 18, $1821(1976)$

(13) J. M. Brillouet, P. R. Coulet, and D. C. Gautheron, Biotechnol. Bioeng., $19,125(1977)$

Recelved for review July 25, 1978. Accepted October 11, 1978. This investigation was supported in part by "Délégation Génẻrale á la Recherche Scientifique et Technique" Grant 76.7 .0920 . 